\title{
ON-FARM VERIFICATION OF LINSEED AND SESAME VARIETY FOR FALLOW-FALLOW-T AMAN RICE CROPPING SYSTEM IN SYLHET REGION OF BANGLADESH
}

\author{
M. I. Nazrul \\ On-Farm Research Division, Bangladesh Agricultural Research Institute (BARI) \\ E-mail: mi_nazrul@yahoo.com; m.i.nazrul@gmail.com
}

Key words: Sesame, linseed, on-farm trial, fallow land, cropping system

\begin{abstract}
A field experiment was conducted during rabi and kharif seasons of 2014-15 and 2015-16 to find out suitable linseed and sesame genotypes to fit in the Fallow-Fallow$\mathrm{T}$. aman rice cropping system under AEZ 20 in Sylhet region of Bangladesh. This experiment was laid out in a randomized complete block design (RCBD) with six dispersed replications. It was revealed that among the different linseed varieties, the genotype Zokiganj-local gave the maximum number (31.40) of capsules plant ${ }^{-1}$ and 1000 -seed weight $(4.01 \mathrm{~g})$ with the highest seed yield $\left(1003 \mathrm{~kg} \mathrm{ha}^{-1}\right)$. Similarly, sesame var. BARI Til-4 provided maximum number of capsules plant $^{-1}$ (71.33), seeds plant ${ }^{-1}$ (70.33) and highest 1000-seed weight (3.012g), which resulted the highest seed yield $\left(1150 \mathrm{~kg} \mathrm{ha}^{-1}\right)$ yield in arable fallow land of Sylhet region. The lowest seed yield 782 and $840 \mathrm{~kg} \mathrm{ha}^{-1}$ of linseed and sesame was produced by the genotypes Patuakhali local and the var. BARI Til-3, respectively.
\end{abstract}

\section{Introduction}

Sylhet region of Eastern Bangladesh is dominated by drought prone rice based rainfed ecosystem as about 182000 ha of arable land remainse fallow during kharif 1 season. Sesame (Sesamum indicum L.) is one of the most ancient oilseed crops (Ashri, 1998; Bedigan and Harlan, 1986) of the world. It is the second largest source of edible oil in Bangladesh next to Brassica both in respect of acreage and production (Anonymous, 1989) and can be cultivated both in rabi (winter) and kharif (summer) season. It occupied 38866 ha of land and produced 25000 tons of seed with a yield of $640 \mathrm{~kg} \mathrm{ha}^{-1}$ (BBS, 2004). Sesame seeds have special significance for human nutrition on account of its high content of sulfur amino acids and phytosterols (Pathak et al., 2014).

Sesame oil-cake is a good feed for poultry, fish, cattle, goat, sheep etc. Sesame is a drought tolerant oil seed crop, which are grown successfully in the early summer (March-May) of Bangladesh under rain fed condition. Linseed (Linum usitatissimum L.) is an annual herb belonging to the family Linaceae, which is commonly found in Asia (Fernald, 1950). Linseed is basically known as a crop of industrial importance and used in paint and varnish industries, which contains 33-43\% oil of drying type and $24 \%$ protein (Vereshagin et. al., 1965). Its oil has high percentages of unsaturated fatty acids and $17 \%$ linoleic acid (McHughen, 1990). It is also used for making linoleum, oil cloth, printer's ink, soap and patent leather. Linseed can play an important role in the production of alternative diesel fuel (Nabi and Hoque 2008; Ariharan et al, 2015). The climatic and soil condition of Bangladesh is suitable for the production of linseed crop. Nematallahi and Saeidi (2011) found significant differences in the response of several linseed genotypes to drought, with some being drought tolerant and others being 
drought sensitive. In Sylhet region, 164000 ha of land remain fallow during dry winter season because of varying degrees of existing soil moisture. As both sesame and linseed are considered as drought tolerant oil seed crops, they are presumed to be cultivated economically in the drought prone areas of Bangladesh. Therefore, the present investigation was carried out to assess the performance of linseed and sesame varieties under rainfed conditions for Sylhet area.

\section{Materials and Methods}

The experiment was conducted at multi location testing (MLT) site, Zokiganj during rabi and kharif-I seasons of 2014-15 and 2015-16 to select suitable linseed and sesame genotypes to fit into the Fallow-Fallow-T. (Transplanted) aman rice cropping system under AEZ 20 in Sylhet region of Bangladesh. This is located in between $24^{0} 51^{\prime}$ and $25^{\circ} 00^{\prime}$ north latitudes and $92^{0} 13^{\prime}$ and $92^{\circ} 30^{\prime}$ east longitudes and on an altitude of 10 meters. Total cultivable land in the area is 11210 ha, which covered 70\% single cropped, 63\% double cropped and 88\% triple cropped with cropping intensity 169\%. The area is dominated by medium land with clay loam and loamy soils. Major crops are paddy, mustard, sesame, linseed, potato, and winter vegetables. The dominant cropping patterns are fallow-fallow-T. aman rice, fallow- T. aus riceT. aman rice, vegetable-T. aus rice-T. aman rice and Boro rice-fallow-fallow. The monthly temperature and rainfall for the experimental site are indicated in Figures 1 and 2 . The average climatic data of Sylhet shows that the mean annual minimum temperature was $16.20{ }^{\circ} \mathrm{C}$ and the mean annual maximum temperature was $33.7^{\circ} \mathrm{C}$ and the annual mean temperature was nearly $17.15^{\circ} \mathrm{C}$.

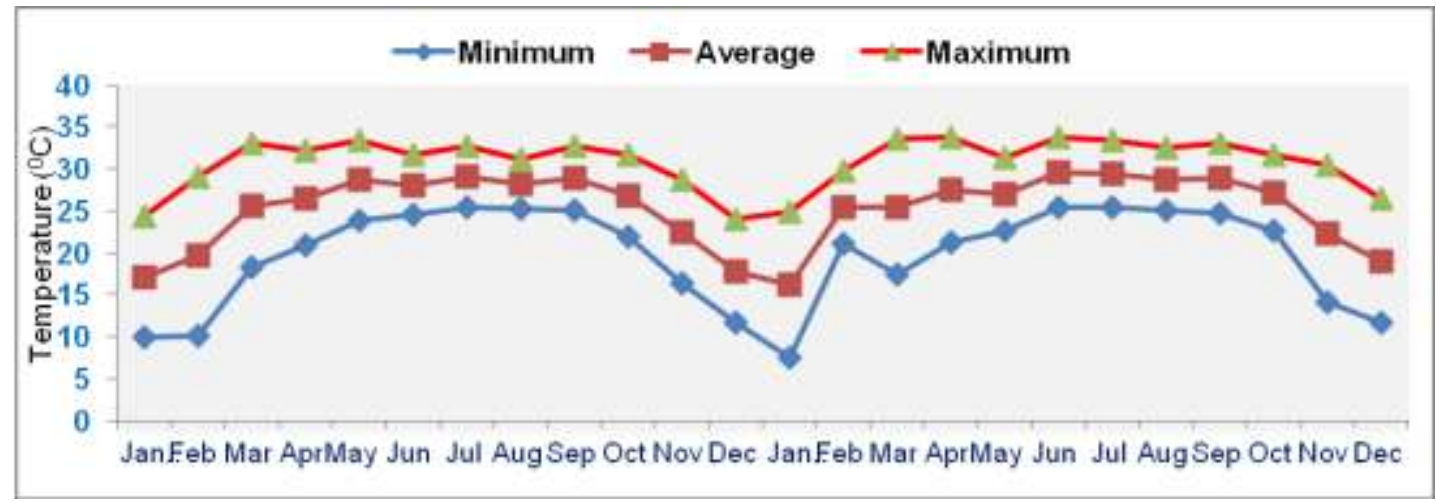

Fig. 1. Minimum, maximum and mean temperature $\left({ }^{0} \mathrm{C}\right)$ pattern in Sylhet of Bangladesh

As indicated in Figure 2, rainfall of the area is uni-modal, usually occurring during April to October, and total annual rainfall reached to $3372 \mathrm{~mm}$; whereas in December no rain at all and lowest amount of rainfall occurs in January followed by February. However, in rest of the months total rainfall was ranged from $112 \mathrm{~mm}$ to just below $200 \mathrm{~mm}$. Rainfall increases gradually from the month of May and continued up to September.

This experiment was laid out in a randomized complete block design (RCBD) with six dispersed replications. There were four different genotypes of linseed (var. BARI Tishi-1: Nila, NoakhaliLocal, Patuakhali-Local and Zakiganj-Local) and sesame (T-6, BARI Til-2, BARI Til-3 and BARI Til-4) with seed rate 8.0 and $7.5 \mathrm{~kg} \mathrm{ha}^{-1}$, respectively. The unit plot size was $10 \mathrm{~m} \times 10 \mathrm{~m}$. Seeds were sown in broadcast method. 
On-Farm Verification of Linseed and Sesame Variety for Fallow-Fallow-T Aman Rice

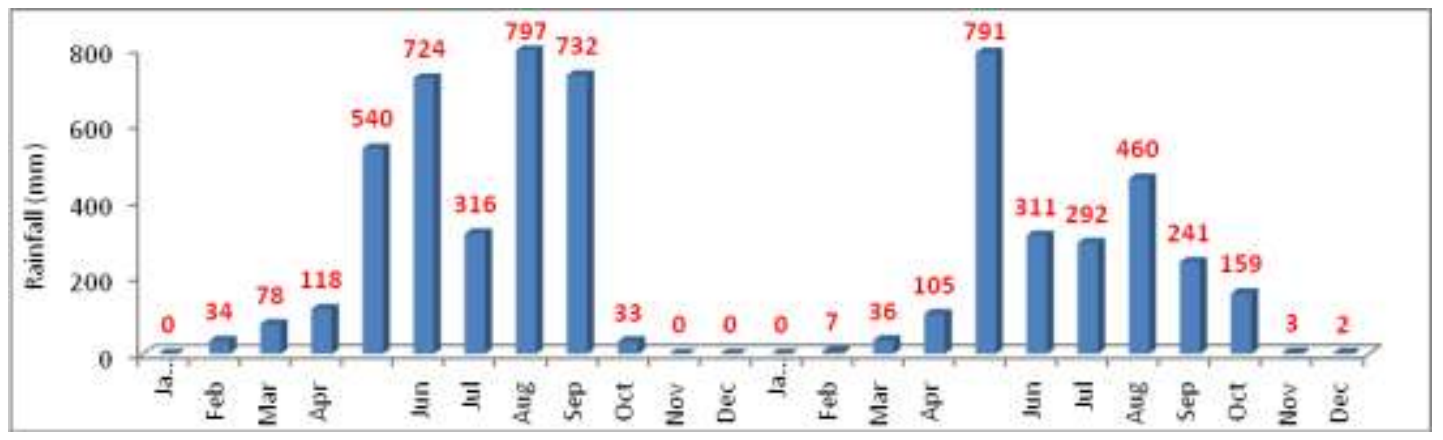

Fig. 2. Annual rainfall (mm) pattern in Sylhet of Bangladesh

The seeds of linseed varieties were sown on 5-7 December and harvested on 10-15 March; on the contrary, sesame seeds were sown on 15-18 March and the crop harvested at full maturity on 12-15 June in 2014-15 and 2015-16, respectively. The seed yield was adjusted to 8\% moisture content. The fertilizer nutrients NPKS (38-13-20-8 for linseed and 56-23-40-18 kg $\mathrm{ha}^{-1}$ for sesame) were applied in the form of urea, triple superphosphate (TSP), muriate of potash (MoP) and gypsum, respectively (FRG, 2012). All fertilizers were applied as a basal during final land preparation. Plant protection measures and different intercultural operations were taken as and when necessary to raise healthy crops. The recorded data were statistically analyzed and mean values were separated by LSD test following Gomez and Gomez (1984).

\section{Results and Discussion}

\section{Crop calendar in study area}

The following seasonal activities were done during conducting the trial at farmers field (Fig. 3). Generally, aus rice transplanting was started in March and subsequent aman rice during the mid June to mid July and harvested within 2nd week of November. But in Sylhet area, transplantation of aus rice being depended on rainfall and was done in early May. This delayed transplantation of aus rice, ultimately hampered the timely cultivation of subsequent $\mathrm{T}$. aman rice and resulting delay sowing of rabi crops. To overcome this situation farmers cultivate local cultivars with less care and crop management practices.

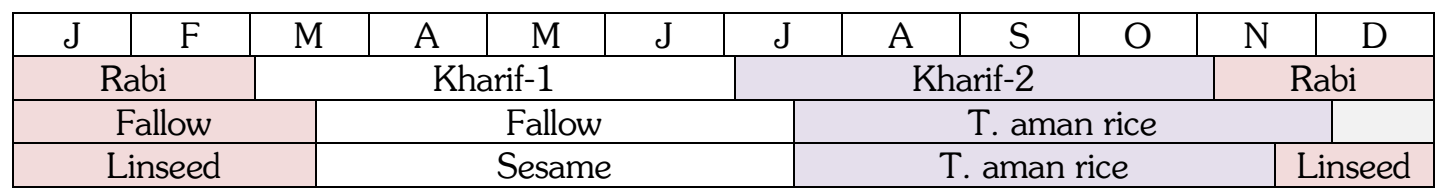

Fig. 3. Seasonal activity calendar showing two crops in cropping pattern of study area

\section{Crop: Linseed}

It was revealed from the experimental results that among the different linseed varieties, the number of plant $\mathrm{m}^{-2}$ was non-significant; however, numerically the maximum number of plant $\mathrm{m}^{-2}$ was observed in BARI Tisi-1(Nila) followed by genotype Patuakhali-local. Plant height was significantly influenced where the highest plant height was found in var. BARI Tishi-1 (64.85 $\mathrm{cm})$ while the shortest $(52.73 \mathrm{~cm})$ in genotype Noakhali-local. Number of capsules in each 
individual is an important yield contributing characters of linseed crop. The maximum number of capsules plant ${ }^{-1}$ was recorded in linseed genotype Zakiganj-local (31.40) that was statistically followed by var. BARI Tisi-1 (21.28); while minimum number in Patuakhali-local (19.13). The number of seeds capsule ${ }^{-1}$ was non-significant. Among tested genotypes, Zakiganj-local produced maximum 1000 -seed weight $(4.01 \mathrm{~g})$ followed by Noakhali-local $(3.66 \mathrm{~g})$ and the lowest in var. BARI Tishi-1 (3.57 g). Zaj c (2005) reported that the productivity of linseed crop largely depends on its morphological characters associated with foliage. The maximum seed yield (1003 kg ha-1) was recorded in Zakiganj-local that was statistically identical with Noakhalilocal $\left(820 \mathrm{~kg} \mathrm{ha}^{-1}\right)$. However, the lowest seed yield $\left(782 \mathrm{~kg} \mathrm{ha}^{-1}\right)$ was found in Patuakhali-local.

Table 1. Seed yield and yield attributes of linseed varieties under on-farm trial during the rabi season of 2014-16; (pooled)

\begin{tabular}{lcccccc}
\hline \multicolumn{1}{c}{ Variety } & $\begin{array}{c}\text { Plants m } \\
(\mathrm{cm})\end{array}$ & $\begin{array}{c}\text { Plant height } \\
(\mathrm{cm})\end{array}$ & $\begin{array}{c}\text { Capsules } \\
\text { plant }^{-1}(\text { no. })\end{array}$ & $\begin{array}{c}\text { Seeds } \\
\text { capsule }^{-1}(\text { no. })\end{array}$ & $\begin{array}{c}\text { 1000-seed } \\
\text { weight }(\mathrm{g})\end{array}$ & $\begin{array}{c}\text { Seed yield } \\
\left(\mathrm{kg} \mathrm{ha}^{-1}\right)\end{array}$ \\
\hline BARI Tishi-1 & 221 & 64.85 & 21.28 & 7.22 & 3.57 & 790 \\
Noakhali-local & 191 & 49.55 & 20.63 & 7.37 & 3.66 & 820 \\
Patuakhali-local & 207 & 52.73 & 19.13 & 7.53 & 3.64 & 782 \\
Zakiganj-local & 201 & 50.80 & 31.40 & 7.73 & 4.01 & 1003 \\
\hline CV (\%) & 8.21 & 3.69 & 20.55 & 7.53 & 4.74 & 11.41 \\
LSD $(0.05)$ & NS & 4.17 & 9.6 & NS & 0.6 & 193.50 \\
\hline
\end{tabular}

\section{Crop: Sesame}

The result showed that plant height, capsules plant ${ }^{-1}$, seeds capsule ${ }^{-1}$, 1000-seed weight and seed yield were significantly influenced by different genotypes of sesame except plants $\mathrm{m}^{-2}$. It was noted from the experimental results that among the different sesame genotypes, the maximum plant height $(101.10 \mathrm{~cm})$ was found in the var. BARI Til-4 followed by BARI Til-2 $(99.89 \mathrm{~cm})$ and T-6 $(99.83 \mathrm{~cm})$. But, the var. BARI Til-4 produced the maximum number of capsules plant ${ }^{-1}$ (71.33) which was statistically similar to var. BARI Til-2 (68.67) and T-6, while var. BARI Til-3 produced the lowest number of capsules plant ${ }^{-1}(50.33)$. These results are in agreement with findings of Tiwari et al. (2000) and Kathiresan (2002). They reported that the number of capsules plant ${ }^{-1}$ varied significantly in different cultivars.

Number of seeds capsule ${ }^{1}$ was significantly influenced by varieties The var. BARI Til- 4 produced the highest number of seeds capsule ${ }^{-1}(70.33)$ followed by BARI Til-2 whereas var. BARI Til-3 produced the lowest number of seeds capsule ${ }^{-1}$ (53.00). These findings corroborated with the findings of Nandita et al. (2009) and Kathiresan (2002). Variable effect of varieties on seeds capsule ${ }^{-1}$ in sesame plant was also reported by Begum et al. It is stated that among the different sesame varieties, BARI Til-4 yielded maximum 1000-seed weight $(3.12 \mathrm{~g})$ followed by BARI Til-2 and T-6 where as var. BARI Til-3 produced lowest 1000-seed weight $(2.81 \mathrm{~g})$. The seed yield of sesame are generally resulted the cumulative effect of capsules plant ${ }^{-1}$, seeds capsule ${ }^{-1}$ and 1000 -seed weight (Rahman et al., 1995). It was observed that there was significant difference in seed yield plant ${ }^{-1}$ among the varieties. The var. BARI Til-4 produced the maximum seed yield plant ${ }^{-1}\left(1150 \mathrm{~kg} \mathrm{ha}^{-1}\right)$ followed by BARI Til-2 (1142 kg $\left.\mathrm{ha}^{-1}\right)$ while var. BARI Til-3 gave the lowest seed yield $\left(840 \mathrm{~kg} \mathrm{ha}{ }^{-1}\right)$. These results were supported by other researcher (Khan et al., 2009). 
On-Farm Verification of Linseed and Sesame Variety for Fallow-Fallow-T Aman Rice

Table 2. Seed yield and yield attributes of sesame varieties under on-farm trial during the kharif season of 2014-16 (pooled).

\begin{tabular}{lcccccc}
\hline Variety & $\begin{array}{c}\text { Plants m } \\
\text { (no.) }\end{array}$ & $\begin{array}{c}\text { Plant height } \\
\text { (cm) }\end{array}$ & $\begin{array}{c}\text { Capsules } \\
\text { plant }^{-1}(\text { no. })\end{array}$ & $\begin{array}{c}\text { Seeds capsule }^{-1} \\
\text { (no.) }\end{array}$ & $\begin{array}{c}1000-\text { seed } \\
\text { weight }(\mathrm{g})\end{array}$ & $\begin{array}{c}\text { Seed yield } \\
\left(\mathrm{kg} \mathrm{ha}^{-1}\right)\end{array}$ \\
\hline T-6 & 41.23 & 99.83 & 65.33 & 61.33 & 2.86 & 980 \\
BARI Til-2 & 37.23 & 99.89 & 68.67 & 67.33 & 2.94 & 1142 \\
BARI Til-3 & 44.57 & 95.76 & 50.33 & 53.00 & 2.81 & 840 \\
BARI Til-4 & 40.57 & 101.10 & 71.33 & 70.33 & 3.12 & 1150 \\
\hline CV (\%) & 9.61 & 1.25 & 8.33 & 8.92 & 7.58 & 7.02 \\
LSD $_{(0.05)}$ & NS & 2.57 & 10.21 & 11.69 & 0.44 & 144.00 \\
\hline
\end{tabular}

\section{Conclusion}

The result showed that sesame var. BARI Til-4 produced higher seed yield followed by BARI Til-2 but in case of linseed var. Zokiganj-local out-yielded the other local as well as BARI developed linseed var. BARI Tishi-1. So, local variety of linseed should be given priority and yield could be enhanced by proper cultivation program.

\section{Acknowledgements}

Authors are gratefully acknowledged Bangladesh Agricultural Research Institute, Gazipur and Metrological Department, Sylhet for providing financial help and logistic support and weather data, respectively. Thanks are also extended who contributed compile and editing of the manuscript.

\section{References}

Anonymous. 1989. Statistical year book of Bangladesh. Statistics Division, Ministry of Planning, Government of the People`s Republic of Bangladesh, Dhaka, pp: 166.

Ariharan V. N., V. N. Meena Devi and P. N. Prasad. 2015. Linseed (Linum isitatissimum L.) oils An alternative fuel source as biodiesel. Res. J. Pharmaceutical, Biol. Chem. Sci. 6(1): 15271531

Ashri. 1998. Sesame breeding. Plant Breeding, Revised Edition, 16: 179-228.

Bedigan D. and J. R. Harlan, 1986. Evidence for the cultivation of sesame in the ancient world. Econ. Bot., 40: 137-154.

Begum, R., M. A. Samad, M. R. Amin, D. B. Pandit, and M. A. Jahan. 2001. Effect of row spacing and population density on the growth and yield of sesame. Bangladesh J. Agril. Sci., 28(2): 311-316.

Fernald, M. L. 1950. Gray's Manual of Botany. Eighth edition (Corrected Printing, R. C. Rollins, 1970). D. Van Nostrand Company, New York, NY. p.1632.

Gomez, K. A. and A. A. Gomez. 1984. Statistical Procedures for Agricultural Research. 2nd Edn. John Wiley and Sons. New York. P. 194.

Kathiresan, G. 2002. Response of sesame (Sesamum indicum L.) genotypes to levels of nutrients and spacing under different seasons. Indian J. Agron., 47: 537-540. 
M.I. Nazrul

Khan M. A. H., N. A. Sultana, M. N. Islam and M. Hasanuzzaman. 2009. Yield and yield contributing characters of sesame as affected by different management practices; Am.- Eur. J. Sci. Res. 4 (3): 195-197.

McHughen, A. 1990. "Flax (Linumusitatissimum L.): In Vitro Studies "Biotechnology in Agriculture and Forestry"; 10: 502-514.

Mondal, R. I. and M. A. Wahab. 2001. Production Technology of Oil crops. Oil Seed Research Centre, Bangladesh Agricultural Research Institute, Gazipur, Bangladesh. p.73

Nabi, M. N. and S. M. N. Hoque. 2008. Bio-diesel production from linseed oil and performance study of a diesel engine with diesel biodiesel. J. Mech. Eng. 39 (1): 40-44

Nandita R., S. M. A. Mamun and M. S. Jahan. 2009. Yield performance of sesame (Sesamum Indicum L.) varieties at varying levels of row spacing; Res. J. Agric. Biol. Sci., 5(5): 823827.

Nematallahi Z, Saeidi G. 2011. Study of drought tolerance in some flax genotypes. Iran J. Water Res. 25(1): 57-66.

Pathak, N., A. K. Rai, R. Kumari, K. V. Bhat. 2014. Value addition in sesame: A perspective on bioactive components for enhancing utility and profitability. Phcog Rev. 8: 147-55.

Rahman, M. M., T. S. Hossen, A. A. A. Muhsi, M. A. Quadir and J. Haider, 1995. Seasonal variations in some physiological characters of sesame (Sesamum indicum L.); Bangladesh J. Bot., 24: 47-51.

Tiwari, K. P., K. P. Namdeo, K. N. Namdeo, J. Girish and G. Jha. 2000. Effect of nitrogen and sulphur on growth, yield and quality of sesame (Sesamum indicum L.) varieties. Res. Crops, 1: 163-167.

Vereshagin, A. G. and G. V. Novitskaya. 1965. The Triglyceride Composition of Linseed Oil. J. Am. Oil Chem. Soc., 42: 970-974.

Zaj c, T. 2005. Assimilation area and yielding of linseed cultivars depending on sowing density and mineral treatment. Acta Agraria et Silvestria series Silvestris, 45: 65-76. 